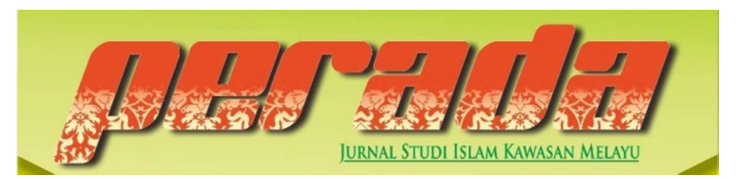

Perada: Jurnal Studi Islam Kawasan Melayu

P-ISSN 2656-7202 E-ISSN 2655-6626

Volume 2 Nomor 2, Juni-Desember 2019

DOI: $10.35961 /$ perada.v2i2.43

\title{
CORAK PEMIKIRAN POLITIK RAJA ALI HAJI (1808-1873)
}

\author{
Muhammad Lazim \\ STAIN Sultan Abdurrahman Kepulauan Riau \\ lazimkurdi12@gmail.com
}

\begin{abstract}
ABSTRAK
Raja Ali Haji adalah seorang bangsawan Melayu keturunan Bugis. Seorang ulama, pujangga sekaligus negarawan yang paling menonjol dan disegani di Kerajaan Riau-Lingga yang berpusat di Pulau Penyengat pada akhir abad ke-19. Penelitian ini disusun dengan metode kualitatif melalui pendekatan historis yang instrumen pengumpulan datanya menggunakan kajian kepustakaan (library research). Data dalam penelitian ini diambil dari karya-karya Raja Ali Haji yang memiliki fokus tema tentang pemikiran politik.Temuan yang diperoleh menunjukkan sistem politik ideal bagi dunia Melayu dalam pandangan Raja Ali Haji adalah sistem kerajaan yang bersendikan syari'at Islam (theo-monarki). Aktifitasnya sebagai praktisi politik serta matangnya tradisi intelektualitas melalui interaksinya dengan teks-teks klasik dari Al-Ghazâli, Al-Mawardi, dan ulama lainnya memberikan corak etis yaitu corak yang memberikan penekanan terhadap etika pemegang kekuasaan. Tetapi, pada saat yang sama pemikiran politik Raja Ali Haji juga termasuk dalam kategori corak hukum karena mengemukakan teoriteori yang berfokus pada teori legitimasi penguasa dari sudut pandang hukum Islam.
\end{abstract}

Kata kunci: Sistem kerajaan yang bersendikan syari’at, Corak etis, Corak hukum.

Abstract: Raja Ali Haji is a Malay noble of Bugis descent. A cleric, poet and statesman who was the most prominent and respected in the Riau-Lingga Kingdom which was centered on Penyengat Island at the end of the 19th century. This research was compiled with qualitative methods through a historical approach in which the data collection instruments used library research. The data in this study are drawn from the works of Raja Ali Haji which focuses on themes of political thought. The findings obtained indicate that the ideal political system for the Malay world in the view of Raja Ali Haji is a royal system based on Islamic shari'a (theomonarchy). Its activities as political practitioners as well as the maturation of the intellectual tradition through its interaction with classical texts from Al-Ghazli, Al-Mawardi, and other scholars provide an ethical Style, which emphasizes the ethics of power holders. But, at the same time Raja Ali Haji's political thought is also included in the category of legal style because it presents theories that focus on the legitimacy theory of the ruler from the standpoint of Islamic law.

Keywords: Royal system based on Islamic shari'a, Ethical style, Legal style. 


\section{PENDAHULUAN}

Lintasan sejarah peradaban manusia mempertontonkan parade panjang distorsi kekuasaan yang dilakukan oleh manusia. Mulai dari penyalahgunaan kekuasaan (abuse of power) berupa pengabaian hak-bak warga bangsa, korupsi, kolusi, dan nepotisme (KKN), monopoli sumber-sumber perekonomian, perilaku melampaui batas semisal mengbilangkan bak bidup dan kemerdekaan ${ }^{1}$, sampai merampas kekuasaan Tuban dalam bakimiyah-Nya babkan rububiyah dan ulubiyah-Nya Allab SWT sebagaimana yang dilakukan oleh Fir'aun dan Namrud' dan para pewarisnya. Maka tak mengherankan jika kemudian muncul banyak pemeo dan stigma negatif tentang politik dan kekuasaan. Sebut saja misalnya ungkapan bahwa dunia politik adalah dunia yang kotor, atau adagium yang terkenal dari Lord Acton ${ }^{3}$ : power tends to corrupt, and absolute power corrupts absolutely (kekuasaan cenderung korup/rusak, dan kekuasaan yang diselenggarakan secara mutlak akan korup secara mutlak pula).

${ }^{1}$ Lihatlah misalnya informasi Al-Qur'an tentang perilaku Fir'aun yang menimpakan siksa yang sangat berat kepada Bani Israil, menyembelih anak laki-laki dan membiarkan hidup anak-anak perempuan mereka, sebagaimana yang termaktub dalam QS. Al-Qashash [28]: 4, QS. Al-Baqarah [2]: 49, QS. Ibrâhîm [14]: 6, QS. Ghâfir [40]: 25

${ }^{2}$ Lihatlah kepongahan Fir'aun dalam QS. Al-Qashash [28]: 38 dan QS. Al-Nâzi'ât [79]: 24, dan kisah perdebatan Namrud dan Nabi Ibrahim dalam QS. Al-Baqarah [2]: 258

${ }^{3}$ Nama lengkap Lord Acton adalah John Emerich Edward Dalberg-Acton. Acton merupakan nama kebangsawanan terkait statusnya sebagai Baron. Dia lahir di Naples pada tanggal 10 Januari 1834. Ayahnya adalah Sir Richard Dalberg Acton. Keluarga Acton adalah keluarga Katolik Romawi. menjadi anggota House of Commons (parlemen) mewakili wilayah Carlow 1859-1865. Pada tahun 1872 dia mendapatkan gelar kehormatan Doctor of Philosophy dari Universitas Munich. Pada tahun 1888 Universitas Cambridge memberikan gelar kehormatan LL.D, dan pada tahun 1889 mendapatkan gelar kehormatan D.C.L. dari Universitas Oxford. Lihat: http://anomalisemesta.blogspot.com/2007/10/to koh_22.html, diunduh pada tanggal 17 Agustus 2018
Memang tak salah seluruhnya manakala publik mempunyai persepsi bahwa dunia politik adalah dunia yang kotor atau kekuasaan cenderung korup/rusak karena memang fakta empiris yang dipertontonkan dunia politik dan kekuasaan sebagian besarnya memang seperti itu, hanya saja yang kurang tepat ketika persepsi ini digeneralisasi serta melihat kenyataan ini dari sisi moral baik dan buruk yang akan berimplikasi pada merendahkan dunia politik. Padahal langkah yang lebih tepat adalah membawa kesadaran bahwa watak politik yang memang bisa disalahgunakan dan dikorupsi, lalu melakukan sentuhansentuhan perubahan karena politik dan kekuasaan - yang terkait dengan hajat hidup warga bangsa dan tegaknya agama di muka bumi ini - haruslah dikontrol, bukan dijauhi dan dipandang rendah serta dikembalikan kepada rel yang semestinya, mensibghab ${ }^{4}$ nya dengan warna, akhlâq, dan spiritualitas Islam.

Dalam konteks mengembalikan politik kepada rel yang tepat, lalu mensibghahnya dengan nilai islam inilah peranan ulama menemukan signifikansinya. Pola relasi ulama - umara tersebut tidak dapat dipisahkan satu dan yang lainnya. Dalam lintasan sejarah politik Islam, relasi antara khalifah, raja, ataupun sultan dan ulama berjalan seirama, hal ini

${ }^{4}$ Sibghah berasal dari bahasa Arab yang sudah diadopsi ke dalam bahasa Indonesia yang bermakna celupan, yakni celupan iman kepada Allah tanpa disertai kemusyrikan. (Lihat: KBBI edisi kelima, aplikasi luring resmi Badan Pengembangan dan Pembinaan Bahasa Kementerian Pendidikan dan Kebudayaan Republik Indonesia)

Sebagaimana firman Allah dalam Q.S. AlBaqarah/2: 138

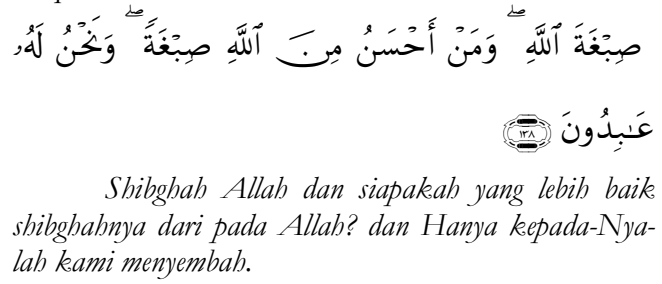


lantaran antara tanggungjawab nubuwwah (menegakkan ajaran kenabian) yang ada di pundak ulama dan amanah bukêmah (mengelola pemerintahan) yang diemban sang raja dapat diselaraskan. Pola hubungan yang serasi ini digambarkan oleh Khalid Hussain laksana dua permata yang sama besar harganya dalam satu cincin (two diamonds in one ring) $)^{5}$

Adapun pada latar sejarah Islam Melayu ${ }^{6}$ yang dalam pendapat para ahli disebutkan bahwa Islam merupakan unsur utama penopang sebuah budaya politik kerajaan, para ulama mengambil posisi "aman" dengan merapat pada institusi kerajaan untuk berperan sebagai aktor utama dalam proses institution building. Milner menjelaskan, ulama menjadi aktor intelektual dalam penerjemahan Islam dalam kerangka tradisi politik lokal melayu yang berorientasi pada raja itu. Syahid mengungkapkan bahwa para ulama menciptakan "ruang kososng", di mana mereka sebagai aktornya leluasa mengisi

${ }^{5}$ Khalid Hussain (ed.), Taj as-Salatin, sebagaimana dikutip oleh Achmad Syahid, Pemikiran Politik dan Tendensi Kuasa Raja Ali Haji, (Jakarta: Puslitbang Lektur Keagamaan Badan Litbang dan Diklat Departemen Agama RI, 2009), h. 3

${ }^{6}$ Terdapat perbedaan pandangan para ahli tentang pemaknaan sebutan Melayu dan Bangsa Melayu. Van Ronkel menyebut Melayu adalah orang yang bertutur bahasa Melayu dan mendiami Semenanjung Tanah Melayu, Kepulauan RiauLingga, serta beberapa daerah di Sumatera, khususnya di Palembang. Baca Ph. S. van Ronkel, Adat Istiadat Raja-Raja Melayu (Leiden; Brill, 1919), 34. Sedangkan Alatas mendefinisikannya sebagai alam Melayu yang meliputi Semenanjung Tanah Melayu, Singapura, Indonesia, Filipina, tetapi tidak termasuk Papua New Guinea dan pulau-pulau di Melanisia. Baca S. H. Alatas, Mitos Pribumi Malas (Jakarta, LP3ES, 1988), h.47. Konstitusi Malaysia bahkan mendefinisikan melayu sebagai identitas bagi mereka yang menganut agama Islam, berbicara dalam bahasa Malaysia, mengamalkan adat istiadat Melayu dan berkewarganegaraan Malaysia. Baca Alfitra Salam, Mencari Akar Budaya Politik Malaysia, pengantar buku "Islam dan Etnisitas Perspektif Politik Melayu, Hussin Mutalib" wacana intelektual keislaman yang berbasis pada institusi kerajaan itu. Dalam proses ini, para ulama memperoleh manfaat besar, terutama karena mereka dapat dengan halus menempatkan diri pada puncak piramida pengaruh, bahkan kemudian secara alamiah memanfaatkan institusi kerajaan sebagai pusat syaraf distribusi kegiatan intelektual Islam. $^{7}$ Hubungan simbiosis mutualisme yang terjalin antara raja dan ulama pada latar Kerajaan Melayu dan bahkan berbagai penjuru dunia Islam merupakan buah dari jaringan guru dan murid "hubungan vertikal" antara Timur Tengah dan Nusantara. ${ }^{8}$ Selain juga buah dari perdagangan internasional.

Di antara sampel ulama rabbani yang memerankan fungsi sebagai aktor utama dalam institution building di Kerajaan Melayu adalah Raja Ali Haji. Kontribusi, kiprah, dan sumbangsihnya dalam proyek institution building ini sangatlah kentara, terutama di bidang intelektual melalui sejumlah karyanya yang memberikan warna dan pengaruh nyata. Patut disayangkan, khazanah intelektual dan budaya yang diwariskannya belum banyak dikaji dan diperkenalkan kepada para pewarisnya (masyarakat nusantara), terbukti ketika berbicara tentang politik Islam, kita masih berkiblat kepada pandangan ulama dari Timur Tengah baik klasik maupun modern.

Penelitian kualitatif berbasis kepustakaan dengan interpretasi, koherensi intren dan kesinambungan historis sebagai metode analisis data ini mencoba untuk mendapatkan gambaran tentang pemikiran politik Raja Ali Haji serta berusaha untuk mendapatkan jawaban atas pertanyaan-pertanyan penelitian (research questions) yaitu: Bagaimanakah

${ }^{7}$ Achmad Syahid, Pemikiran Politik, h. 2

${ }^{8}$ Azyumardi Azra, Jaringan Ulama Timur Tengah dan Kepulauan Nusantara Abad XVII dan XVIII: Melacak Akar-Akar Pembaruan Pemikiran Islam Di Indonesia, (Bandung: Mizan, 1998), Cet. Ke-4, h. 105 
narasi politik Islam Raja Ali Haji? Latar sosio-kultur dan sosio-politik seperti apakah yang melingkupi kehidupan Raja Ali Haji sehingga bisa sampai kepada narasi tersebut? Termasuk dalam corak fikih siyasah yang manakah narasi pemikiran politk tersebut?

\section{MANUSIA RABBANI; BIOGRAFI SOSIAL INTELEKTUAL RAJA ALI HAJI}

Nama lengkap Raja ${ }^{9}$ Ali Haji adalah Tengku Haji Ali al-Haji bin Tengku Haji Ahmad bin Raja Haji Asy-Syahîdu fì Sabîlillâh bin Upu Daeng Celak, yang lebih masyhur dengan sebutan Raja Ali Haji. dilahirkan dari rahim Encik Hamidah binti Panglima Selangor, di Pulau Penyengat Indera Sakti yang kala itu merupakan pusat pemerintahan kerajaan Riau Lingga, Johor dan Pahang pada tahun $1808 \mathrm{M}$ dan wafat pada tahun 1873. Datuknya adalah Raja Haji yang merupakan Yang Dipertuan Muda Riau IV dan seorang pahlawan yang termasyhur keberaniannya dalam perjuangan mengusir kolonialisme Belanda, menemui syahîdnya dalam sebuah pertempuran melawan kompeni Belanda di Teluk Ketapang pada tahun $1874 .{ }^{10}$

Ayahnya adalah Raja Ahmad, anak bungsu dari Yang Dipertuan Muda Riau IV Raja Haji yang baru berusia empat tahun kala ayahnya syahîd di Teluk Ketapang. Raja Ahmad merupakan salah seorang deplomat dan tokoh penting dalam bidang politik kerajaan RiauLingga. Ia menjabat sebagai penasehat beberapa orang Yang Dipertuan Muda Riau, termasuk Raja Ja'far, Yang Dipertuan Muda Riau VI (1805-1831 M). Pada tahun 1822 dan 1823 pernah

${ }^{9}$ Raja merupakan gelar yang disematkan bagi keturunan Yang Dipertuan Muda Riau dan sanak familinya yaitu bangsawan yang berasal dari Bugis. Lihat: Hasan Junus, Sejarah Perjuangan Raja Ali Haji Sebagai Bapak Bahasa Indonesia, (Pekanbaru: UNRI Press, 2004), h. 212

${ }^{10} \mathrm{Ibid}$. memimpin misi perdagangan dan penelitian ke Batavia menemui Gubernur Jendral Godart Alexander Gerard Philip Baron van der Capellen. Pada tahun 1826 memimpin kafilah dagang Riau ke daerah Pantai Utara Pulau Jawa, bertemu dengan residen Jepara D.W Punket van Haak. Dan pada tahun 1828 beliau memimpin Rombongan Riau yang hendak menunaikan fardbu haji ke Tanah Suci. ${ }^{11}$

Dari sisi pendidikan, aura ilmu pengetahuan tampak terpancar dari seorang Raja Ali Haji, hal ini mengisyaratkan kokohnya tradisi intelektual yang dimilikinya serta berkualitasnya pendidikan yang diperolehnya. Lahir dari seorang ayah Raja Ahmad Engku Haji Tua yang tergolong intelektual muslim. Junus mengatakan bahwa Raja Ahmad menguasai ilmu falak dan mendalami adat istiadat. ${ }^{12}$ Sebagai seorang putra pejabat istana Raja Ali Haji mendapatkan pendidikan dasarnya dari lingkungan istana Kerajaan Penyengat sendiri. Ia mendapatkan tarbiyah dari tokoh-tokoh terkemuka yang datang dari berbagai daerah. ${ }^{13}$

Di antara ulama yang dimaksud adalah Syaikh As-Saqaf, Syaikh Ahmad Jabarti, Syed Hassan Al-Haddad, Syaikh Ismail bin Abdullah Al-Minkabawi, Syaikh Abdul Ghafur bin Abbas Al-Manduri, Kiai Beranjang, Haji Syahabudin, Haji Abu Bakar Bugis, dan yang lainnya. ${ }^{14}$

${ }^{11}$ Ibid, h. 213-214

${ }^{12}$ Hasan Junus, Raja Ali Haji Budayawan Di Gerbang Abad XX, (Pekanbaru: Unri Press, 2002) h. 51

${ }^{13}$ Junus memberikan istilah the ruling elite bagi anak-anak kaum keraton yang mendapatkan kesempatan pertama menikmati pendidikan berkualitas yang dihadirkan oleh para ulama yang bermastantin di pulau Penyengat kala itu. Ibid, h. 6364

${ }^{14}$ Raja Ahmad dan Raja Ali Haji, Tubfat AlNafis, (Kuala Lumpur: Penerbit Fajar Bakti, 1982), h. 278. Lihat juga: Abu Hassan Sham, Puisi-puisi Raja Ali Haji, (Kuala Lumpur: Percetakan Dewan Bahasa dan Pustaka Kementerian Pendidikan Malaysia, 1993), h. 8 
Sekitar tahun 1827 Raja Ahmad dan Raja Ali Haji pergi menunaikan ibadah Haji ke tanah Mekah. Mereka berdua merupakan anak keturunan Raja Riau yang pertama sekali menunaikan ibadah Haji. kesempatan ini dipergunakan pula oleh Raja Ali Haji untuk menambah pengetahuannya dengan tinggal dan belajar di Mekah untuk beberapa lama. Selama di Mekah, Raja Ali Haji yang masih muda mencurahkan segala waktunya untuk memperdalam bahasa Arab dan ilmu-ilmu yang berkaitan dengan agama dan sempat pula berhubungan dengan Syaikh Daud bin Abdullah Al-Fatani. Dalam beberapa bidang keislaman dan ilmu bahasa Arab Raja Ali Haji sempat belajar dari Syaikh Daud bin Abdullah Al-Fatani yang ketika itu adalah seorang yang terpandang dikalangan masyarakat Melayu di Mekah. Dalam perjalanan ke Mekah itu Raja Ali Haji dan ayahnya telah pula menyempatkan diri berkunjung ke Mesir baru kemudian kembali ke Riau."

Khazanah keilmuan yang dimilikinya mengantarkan Raja Ali Haji menjadi seorang ulama Pulau Penyengat yang paling menonjol dan disegani. Iapun menjadi penasehat sekaligus guru agama bagi beberapa orang Yang Dipertuan Muda yang hidup di zamannya. Mereka adalah Yang Dipertuan Muda Riau VII Raja Abdul Rahman (1831-1844), Yang Dipertuan Muda Riau VIII Raja Ali (1844-1857), Yang Dipertuan Muda Riau IX Raja Abdullah (1857-1858), Yang Dipertuan Muda Riau X Raja Muhammad Yusuf (1858-1911) yang merupakan Yang Dipertuan Muda Riau terakhir. Kedudukan Istimewa ini membuatnya senantiasa terpilih untuk memimpin upacara-upacara keagamaan. Dia juga memikul tanggungjawab untuk mendampingi Yang Dipertuan Muda Riau saat menghadapi sakarât al-maut khususnya

${ }^{15}$ Muhd. Saghir Abdullah, Perkembangan Ilmu Fiqh, h. 128
Yang Dipertuan Muda Riau VIII Raja Ali dan Yang Dipertuan Muda Riau IX Raja Abdullah. Yang dilakukannya saat itu adalah membaca Sûrah Yâsin, mentalqîn mereka dengan membimbing mereka untuk tetap membaca dua kalimah syabâdat, takbîr, dan tabmîd. ${ }^{16}$

Raja Ali Haji meninggal dunia pada tahun $1873 \mathrm{M}$, pada usia sekitar 65 tahun, dan dimakamkan di Pulau Penyengat indera Sakti, tepatnya di kompleks makam Engku Putri Raja Hamida. Makam Raja Ali Haji ini terletak di luar bangunan utampa makam. Karya monumentalnya Gurindam Duabelas diabadikan di sepanjang dinding bangunan makam. Sehingga setiap pengunjung dapat membaca atau mencatat karya agung itu yang bernilai sastra tinggi sekaligus memuat pesan-pesan dakwah yang begitu kental. ${ }^{17}$

\section{LATAR BELAKANG PEMIKIRAN RAJA ALI HAJI}

Ketokohan dan kedudukan intelektual yang diraih Raja Ali Haji tidak mungkin dilepaskan dari kondisi sosiokultur dan sosio-politik yang melingkupi kehidupannya termasuk tokoh-tokoh dan pribadi-pribadi yang dikaguminya, sebagaimana persepsi garis pemikirannya tidak mungkin dipisahkan dari perkembangan pemikiran keagamaan yang berkembang di Ranah Melayu.

Dalam kajian kaum cendikia, Sejarah pendidikan tradisional di Ranah Melayu, ternyata telah dimulai jauh sebelum pendidikan tradisional di Jawa. Menurut catatan van Bruinessen, pendidikan tradisional di Jawa baru ditemukan pada

\footnotetext{
${ }^{16}$ Raja Ahmad dan Raja Ali Haji, Tubfat AlNafis, h. 280

${ }^{17}$ Badiatul Muchlisin Asti, "Raja Ali Haji: Menggores Pesan-pesan Dakwah Lewat Bait-bait Gurindam" http:/ / sosok.kompasiana.com/2018/06/15/rajaali-haji-menggores-pesan-pesan-dakwah-lewatbait-bait-gurindam/ diakses tanggal 15 Juni 2018
} 
abad ke-18 Masehi. ${ }^{18}$ Adapun pendidikan tradisional di Ranah Melayu, sebagaimana kajian Abdullah tentang Pesantren dan Madrasah di Semenanjung Melayu dan Pattani, telah ada sejak awal abad ke-13 $\mathrm{M}^{19}$ pendidikan keagamaan ini diselenggarakan di masjid, surau, dan di rumah-rumah tokoh agama mereka. Tidak ada riwayat yang menyebutkan adaya sistem sekolah pondok pesantren sebagaimana yang telah ada di Kelantan dan Patani. ${ }^{20}$

Penyengat saat itu adalah tanah yang subur bagi pendidikan Islam, tasawuf, dan kesusasteraan. Raja Ja'far amat menyayangi guru-guru Al-Qur'an ${ }^{21}$, menikmati cerita-cerita fiksi dari Timur Tengah $^{22}$. Kondisi ini memungkinkan lahirnya beberapa pengarang di zaman beliau seperti Haji Abdul Wahab dengan saduran Hikayat Gholam. Pada masa Raja Ja'far pula organisasi tasawuf mulai berkembang pesat. Di zaman penerusnya Yang Dipertuan Muda Raja Abdul Rahman kitab Al-Hikam karya Tâjuddin Abul Fadhl Ahmad Ibn Muhammad ibn Abdul Karîm 'Athâillâh diterjemahkan. Bahkan pada generasi berikutnya, masa pemerintahan Raja Ali ibn Raja Ja'far banyak pembesar kerajaan yang turut aktif

${ }^{18}$ Martin van Bruinessen, Pesantren, Madrasah, dan Sekolah, (Jakarta: LP3ES, 1988). Lihat juga: Martin van Bruinessen, Kitab Kuning, (Bandung: Mizan, 1999)

19 Wan Mohd. Shaghir Abdullah, Filologi Melayu, jilid 4, (1995), h. 59-61

Haji, h. 6

20 Abu Hassan Sham, Puisi-Puisi Raja Ali

21 Salah satu buktinya menurut Sham adalah jika ada qari yang datang ke penyengat, guru itu diminta untuk tinggal dua atau tiga bulan untuk mengajarkan Al-Qur'an kepada pegawai dan pembesar Penyengat, kemudian diberinya qari' tersebut hadiah yang lumayan. Lihat: Abu Hassan Sham, Puisi-Puisi Raja Ali Haji, h. 7

22 Salah satu buktinya adalah populernya kisah Alfa Lailab wa Lailah di Penyengat pada pertengahan abad ke-19 sehingga muncul karya adaptasinya di sana seperti Syair Tajul Muluk dan Syair Ibrabim bin Khasib. Abu Hassan Sham, PuisiPuisi Raja Ali Haji, h. 7 dan menjadi pengikut tarekat Naqsyabandiyah.

Terlepas dari reputasi Riau (Pulau Penyengat) di mata bangsa Melayu lainnya, faktanya Raja Ali haji dan manusia zamannya dihadapkan dengan ancaman serius dari bahaya luar yang tidak kuasa mereka kendalikan yang sewaktuwaktu dapat meluluh-lantakkan sendisendi tradisi Melayu yang Islami. Apalagi pemerintah Belanda melakukan penetrasi dengan strategi pengkaburan nilai-nilai Islam yang salah satunya dilakukan oleh Snouck Hurgronje dengan propaganda Islam yang benar adalah Islam yang tidak ada sangkut pautnya dengan kegiatan ekonomi dan politik, yang dikatakannya sebagai Islam ritual atau Islam pribadi.

Sebagai benteng tradisi, maka yang dilakukan Raja Ali Haji dan tokoh-tokoh sezamannya adalah menggaungkan pembaharuan Islam untuk mengatakan bahwa islam yang dipelihara oleh kolonial sebagai alat kekuasaannya itu Islam yang keliru. Islam yang benar ialah yang meniscayakan bukan saja keimanan kepada Allah semata, tetapi juga meniscayakan ikhtiar dan pemikiran untuk mengatasi persoalan zaman. Penjajahan adalah bentuk perbudakan yang bertentangan dengan ajaran Islam yang karenanya harus dilawan. Untuk itu orang Islam harus ambil bagian dalam kehidupan ekonomi, politik, dan kebudayaan, serta tidak boleh berpangku tangan dan menyerahkannya kepada orang lain.

Adapun tokoh-tokoh yang memberikan pengaruh signifikan terhadap persepsi, tradisi ilmiah dan life style Raja Ali Haji, antara lain:

1) Raja Ahmad

Dalam kehidupan Raja Ali Haji, Raja Ahmad memainkan peran sebagai orang tua biologis sekaligus idiologis bagi putranya itu. Hal ini karena ditangannyalah asuhan dan pendidikan dasar yang dikenyam Raja Ali Haji berasal, 
muyv̂l dan kecenderungan yang dimilikinya terwariskan dengan sempurna. Kecintaannya terhadap dunia kepenulisan, perhatian besar terhadap dimensi spiritual yang akhirnya terekspresikan dalam tarekat naqsyabandiyah, bahkan perhatiannya terhadap rekonstruksi sejarah yang diwujudkan lewat tulisanpun diikuti oleh sang putra. Kitab sejarah Tubfat Al-Nafis yang merupakan sebuah epik yang menghubungkan sejarah Bugis di ranah melayu dan hubungannya dengan raja-raja Melayu adalah bukti dari pengaruh kuat yang terwariskan dari ayah ke sang anak ini dari sisi kecenderungan terhadap sejarah. Menurut Virginia Matheson, Tubfat Al-Nafis ditulis Raja Ali Haji bersama orang tuanya. Sangat mungkin, Raja Ali Haji memperbaiki dan menyempurnakan teks yang sebelumnya ditulis Raja Ahmad. ${ }^{23}$ Darah sastrawan Raja Ali Haji menurun dari ayahnya ${ }^{24}$

\section{2) Abû Hâmid Al-Ghazâli}

Perkembangan pemikiran dan spiritualitas Raja Ali Haji secara fundamental dipengaruhi oleh goresan pena Huijatul Islâm Abu Hâmid AlGhazâli. Salah satu indikasi kekaguman Raja Ali haji terhadap teolog besar persia yang juga merupakan salah satu fuqahâ madzhab syâfíi ini dapat diketahui dari frekuensi rujukannya terhadap kitab $I$ bya $\hat{a}^{-}$ Ulûmuddìn yang fenomenal itu. Bahkan dalam kitab Tsamarât Al-Mubimmah yang menguraikan tentang konsepsi politik dan pemerintahan Islam terdapat kemiripan yang amat kentara dengan Ibya 'Ulümuddìn dan at-Tibr al-Masbûk fì

${ }^{23}$ Raja Ahmad dan Raja Ali Haji, Tubfat AlNafis, h. xx. Lihat juga Barbara Watson Andaya dan Virginia Matheson, Pikiran Islam dan Tradisi Melayu,

http://www.rajaalihaji.com/id/article.php?a=Z0R IL $3 \mathrm{c} \% 3 \mathrm{D}=$ diunduh pada 22 Mei 2018

${ }^{24}$ Raja Ali Haji, Sastrawan dan Ulama Melayu,

http:/ / www.riaupos.co/spesial.php?act=full\&id= $405 \& \mathrm{~kat}=7$, diunduh pada tanggal 22 Juni 2018
Nashîhat al-Muluk karya Al-Ghazâli, tidak hanya pada contentnya, tetapi juga pada sistematika bab pembukanya.

Lihat saja misalnya, pada bagian awal kitab Ihyâ' 'Ulûmuddîn yang merupakan karya magnum opusnya, AlGhazâli mengupas tentang ilmu dan urgensinya, adâb al-álim (etika orang yang berilmu), adâb al-muta'allim (etika pencari ilmu). Demikian juga pada at-Tibr alMasbûk. fì Nashîhat al-Muluk. ${ }^{25} \mathrm{Hal}$ ini sama dengan yang dilakukan oleh Raja Ali haji dalam menyajikan pemikiran politiknya dalam kitab Tsamarât Al-Mubimmah.

Relevansi ajaran Al-Ghazâli dengan latar Melayu kala itu adalah karena ia menekankan pentingnya moral sebagai penyangga keimanan dan prilaku manusia dalam relasi sosialnya. Runtuhnya berbagai peradaban suatu komunitas tidak semata-mata dikarenakan mundurnya pemikiran, tetapi lebih dikarenakan keruntuhan sendi-sendi moral para penguasanya. Hal inilah sesungguhnya yang menjadi benang merah antara pemikiran Al-Ghazâli dengan Raja Ali Haji.

Disamping Raja Ahmad dan AlGhazâli, menurut Syahid, pemikiran politik Raja Ali Haji juga sangat dipengaruhi oleh para teolog faqih Sunni seperti Muhammad Idris Al-Syafi'i dengan al-Risâlah-nya, Ibrahim bin Ibrahim AlLaqani dengan Jawharat at-Tauhîd-nya, AlZawzâni dengan Ithâaf al- Murîd 'alâ Jawharat at-Taubîd, Al-Bayjuri dengan Tuhfat al- Murîd 'alâ Jawharat at-Taubîd. ${ }^{26}$

\section{KONTEN FIKIH SIYASAH DALAM PEMIKIRAN RAJA ALI HAJI}

a. Sistem Politik

Basis intelektual yang Islami dan kesertaannya dalam Tarekat Naqsyabandiyah memberikan pengaruh yang signifikan terhadap pandangan politik Raja Ali Haji. Warna Islam yang

${ }^{25}$ Achmad Syahid, Pemikiran Politik, h. 238

${ }^{26}$ Ibid, h. 261 
kental dengan moralitasnya menjadi konsepsi politik Raja Ali Haji yang berorientasi pada ideologi kerajaan; hal tersebut merupakan ekspresi dari hasrat Raja Ali Haji untuk membangun kembali institusi kerajaan yang berbasis Islam, setelah dalam perkembangannya mengalami proses degradasi moral sebagaimana dijelaskan secara rinci dalam Tuhfat al-Nafis. ${ }^{27}$ Raja Ali Haji mengkritik pedas perilaku politik raja-raja Melayu yang dinilai telah menyimpang dari nilainilai Islam, khususnya tentang pengendalian hawa nafsu, telah terabaikan dalam kehidupan politik raja-raja Melayu.

Dalam pandangan Raja Ali Haji, sistem kerajaan merupakan model bangunan politik ideal bagi dunia Melayu. Hal ini tampak sedemikian kuat pada fakta bahwa pemikiran politik yang tertuang dalam karya-karya Raja Ali Haji, teristimewa teks Tsamarât Al-Mubimmah. ${ }^{28}$ Tentu saja sistem kerajaan yang bersendikan syari'at sebagaimana yang diaplikasikan oleh Yang Dipertuan Muda Raja Ali sebagaimana yang dilukiskan oleh Raja Ali Haji dalam Zaman Gemilang Yamtuan Muda Raja Ali. ${ }^{29}$ Bahkan Enthurahman dan Burhanudin mentahbiskan Raja Ali Haji sebagai penggagas bagi kebangkitan kembali

${ }^{27}$ Episode ini terkait dengan perilaku Sultan Mahmud Syah III sebagaimana telah disebutkan dalam Bab II. Lihat pula Raja Ahmad dan Raja Ali Haji, Tuhfat Al-Nafis, h. 345-356

${ }^{28}$ Oman Fathurahman dan Jajat Burhanudin, Raja Ali baji dan Babasa Indonesia, Makalah ditulis atas undangan Pemerintah Kota Tanjungpinang dalam rangka pengusulan Raja Ali Haji sebagai Pahlawan Nasional dan terkodifikasi dalam buku Sejarah Perjuangan Raja Ali Haji Sebagai Bapak Bahasa Indonesia. Lihat Hasan Junus, Sejarah Perjuangan Raja Ali Haji, h. 351-352

${ }^{29}$ Zaman Gemilang Yamtuan Muda Raja Ali adalah Bab ke 52 dalam kitab Tubfat Al-Nafis. Lihat: Raja Ahmad dan Raja Ali Haji, Tuhfat AlNafis, (Kuala Lumpur: Penerbit Fajar Bakti, 1982), h. 341-344 sistem kerajaan dalam dunia Melayu di abad ke-19. ${ }^{30}$

\section{b. Hal Ibwal Pelaksanaan Kekuasaan \\ Bertuah rumah ada tuannya.. \\ Bertuah negeri ada pucuknya.. \\ Elok rumah ada tuannya.. Elok negeri ada rajanya.. ${ }^{31}$}

Ungkapan tersebut di atas merupakan sebuah ungkapan dalam tradisi Melayu yang menyatakan tentang urgensi kepemimpinan dalam sebuah komunitas masyarakat. Faktanya, keberadaan figur seorang pemimpin sangat dibutuhkan dalam komunitas, baik dalam tataran kehidupan berumah tangga, bermasyarakat, terlebih lagi pada tataran kehidupan bernegara. Tradisi Melayu berusaha mendudukkan seorang pemimpin yang mereka sebut sebagai "orang yang dituakan" pada posisi pembimbing, pelindung, penjaga, dan penuntun masyarakat dalam arti luas, baik untuk kepentingan hidup duniawi maupun ukhrawi, menghadirkan sebanyak mungkin kemaslahatan dan meminimalisir mafsadah. Profil pemimpin seperti inilah yang akan mampu menghadirkan negeri elok nan bertuah yang berpotensi dapat memberikan keadilan dan kesejahteraan hidup kepada seluruh lapisan masyarakat. Seorang kepala negara dalam ketatanegaraan Islam memegang amanah kenabian sebagai uli al-amri dalam menjaga risalah dan mengatur urusan dunia, ${ }^{32} \mathrm{Al}-$ Mâwardi menyebutnya karena sangat menentukan dalam penegakan urusan

\footnotetext{
${ }^{30}$ Oman Fathurahman dan Jajat Burhanudin, Raja Ali baji dan Babasa Indonesia,dalam Hasan Junus, Sejarah Perjuangan Raja Ali Haji, h. 352

${ }^{31}$ http://kabarnet.wordpress.com/2018/ 09/02/karakteristik-kepemimpinan-ideal-menurutraja-ali-haji-dan-relevansinya-dengan-prinsipprinsip-tata-kelola-pemerintahan-di-indonesia. diunduh pada tanggal 2 September 2018

${ }^{32}$ Setiawan Budi Utomo, Fikih Kontemporer: Tanya Jawab Politik, Ekonomi, Sosial, dan Kesehatan Kontemporer di Majalah Saksi, (Jakarta: Penerbit Pustaka Saksi, 2000), h. 43
} 
syar'iyyah $^{33}$. Sedangkan Al-Ghazali menyebut imamah sebagai urusan mubimmat yang merupakan landas tumpu bagi upaya pengelolaan agama dan dunia, demi meraih kebahagiaan dunia akhirat. ${ }^{34}$ Bahkan Ibnu Taimiyah mengklasifikasikannya sebagai kewajiban yang asasi dalam agama karena iqamatuddin menurutnya tidak mungkin direalisasikan tanpa eksistensi imam atau pemimpin. ${ }^{35}$

a) Kewajiban Mendirikan Raja dan Tata Cara Pendiriannya

Dalam Bab Pertama, Pasal 1, kitab Tsamarât Al-Mubimmah Raja Ali Haji menyatakan:

"Bermula mendirikan raja itu pada ugama Islam fardu kifayah. Bermula adalah sah pendirian raja itu yaitu dengan tiga sebab. Pertama dengan sebab bai'ah ablil halli wal-aqdi dari pada ulama, yakni dengan sebab dilantik ...." "Kedua, dengan sebab istikblâf yakni menjadikan satu raja akan gantinya \# masa hidupnya, pada yang patut menjadi Raja ...."

"Ketiga, dengan sebab tagallub, yakni dengan kekerasan seorang laki-laki yang mempunyai kuat mengalahkan suatu negeri itu, kemudian menjadilah ia raja dengan dirinya sendiri". ${ }^{36}$

Para ulama ummat telah berkonsensus (ijma) tentang wajibnya hukum mendirikan raja. Meskipun terdapat perbedaan pendapat diantara para mereka tentang landasan argumen kewajiban hukum mendirikan raja

${ }^{33} \mathrm{Ali}$ bin Muhammad bin Habîb AlMâwardi, Al-Ahkkâm As-Sulthâniyyah Wa Al-Wilâyat Al-Diniyyah, (Kuwait: Maktabah Dâr Ibnu Qutaibah, 1409), cet ke-1, h.5

${ }^{34}$ Abû Hâmid Muhammad Al-Ghazâli, AlIqtishâd fi Al-I'tiqâdi, (Ankara: Nur Matbaasi Universitas Ankara, 1962 ), h. 234

${ }^{35}$ Taqiyuddin Ahmad ibn Abdissalâm (Ibnu Taimiyah), Al-Siyâsah Al-Syar'iyyah fì Ishlâbi al-Râंi wal-Ra'iyyah, (Beirut: Dar al-âfaq al-jadîdah, 1403H), h. 138

${ }^{36}$ Raja Ali Haji, Tsamarat Al- Muhimmah, dalam Mahdini, Tsamarât Al-Mubimmab: Pemikiran Raja Ali Haji Tentang Peradilan, Pekanbaru: Penerbit Yayasan Pusaka Riau, 1999, h. 43 tersebut, $^{37}$ namun terlepas dari ikhtilaf tersebut, maka pernyataan Raja Ali Haji tentang hukum mendirikan raja ini menunjukkan pemahamannya mengenai urgensi kepemimpinan dalam kehidupan ummat sebagaimana yang dipahami para fuqaha terdahulu, seperti ungkapan Ibnu Taimiyah berikut:

يجب أن يعرف أن ولاية أمر الناس من أعظم

واجبات الدين بل لا قيام للدين ولا للدنيا إلا بها • فإن بني آدم لا تتم مصلحتهم إلا بالاجتماع لحاجة بعضهم إلى بعض ك ولا بلد لهم عند الاجتماع من رأس.

"Harus diketahui, babwa memimpin dan mengendalikan rakyat adalah kewajiban yang asasi dalam agama. Babkan iqamatuddin tidak mungkin direalisasikean, kecuali dengan adanya kepemimpinan. Sedangkan selurub anak. Adam, mustahil akan mencapai kemaslahatan optimal kalau tidak ada perkumpulan yang mengikat dan memecabkan kebutuban mereka. perkumpulan ini sudah pasti butub seorang pemimpin (untuk mengendalikan)."

Pendapat Raja Ali Haji ini sejalan dengan jumbûr fuqaba dari kalangan Ablussunnah Wal Jamâ'ah, Murï'ah, Syi’ah, mayoritas Mu'tazilah, dan mayoritas Khawârij tentang hal tersebut. ${ }^{39}$

${ }^{37}$ Madzhab pertama berpendapat landasan argumen kewajiban mendirikan raja adalah akal. Mereka berargumen bahwa secara akal sehat manusia membutuhkan seorang za'îm yang melindungi mereka dari kezhaliman, menengahi perselisihan dan sengketa diantara mereka. tanpanya niscaya terjadi kekacauan yang berkepanjangan dalam hidup mereka. adapun madzhab kedua berpendapat bahwa landasan argumen kewajiban mendirikan raja adalah syara' dan bukannya akal. Karena imam melaksanakan kewajiban yang datang dari syara' sebagaimana QS. An-Nisa (4): 59. Lihat: Ali bin Muhammad bin Habib Al-Mâwardi, Al-Abhkâm As-Sulthâniyyah, h. 5

${ }^{38}$ Taqiyuddin Ahmad ibn Abdissalâm (Ibnu Taimiyah), As-Siyâsah Asy-Syar'iyyah, h. 138

39 Wahbah Az-Zuhaili, Al-Figh Al-Islâmî Wa Adillatubu, (Damaskus: Daar Al-Fikr, $1405 \mathrm{H}$ ) cet. Ke- 2, juz. 6, h. 663 
Sedangkan ungkapan Raja Ali Haji bahwa hukum mendirikan raja adalah fardhu kifâyah, ternyata hal tersebut selaras dengan ungkapan Al-Mâwardi dalam kitab

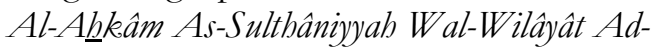
Diniyyah, sebagaimana ungkapannya berikut ini:

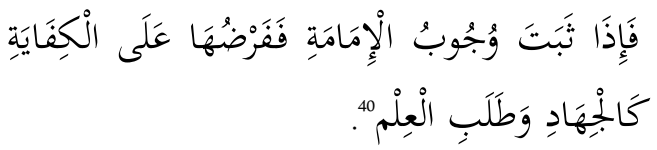

"Ketika telah tetap kewajiban mendirikan raja, maka kewajibannya bersifat fardhu kifâyah sebagaimana kewajiban jibad dan mencari ilmu."

Juga selaras dengan pendapat Qâdhi Abu Ya'la Al-Hanbaliy ${ }^{41}$ dan Zakariyya Al-Anshâri. ${ }^{42}$

Sementara klausul kedua dari Pasal pertama kitab Tsamarât Al-Mubimmah diatas membicarakan tentang tata cara pendirian raja atau pengangkatannya (Kaifiyyah in'iqâd al-imâmah) yang juga sebagaimana kajian para fuqaha, yaitu melalui bai'at ablil balli wal 'aqdi, dengan cara istikblâf, serta dengan cara penguasaan dengan kekuatan dan kemenangan atau taghallub. ${ }^{44}$

Menurut Raja Ali Haji sebab pertama seseorang menjadi raja adalah

${ }^{40} \mathrm{Ali}$ bin Muhammad bin Habîb AlMâwardi, Al-Abkâm As-Sulthâniyyah, h. 4

${ }^{41} \mathrm{Abu}$ Ya'la Muhammad ibn Husain AlFarra', Al-Abhkâm As-Sulthâniyyah Wa Al-Wilâyat Al-Diniyyah, (Beirut: Dâr Al-Kutub Al-'Ilmiyyah, 2000), h. 19

${ }^{42}$ Abu Yahya Zakariyya ibn Muhammad AlAnshari, Fath Al-Wabhab bi Syarh Al-Minhaj, (ttp: Dar Al-Fikr, 2002), h. 185-189

${ }^{43}$ Ahlul Halli Wal 'aqdi adalah sebuah institusi politik yang memiliki wewenang melantik raja setelah sebelumnya menggelar musyawarah. Dengan komposisi terdiri atas beberapa orang lakilaki yang adil dan memiliki reputasi yang baik, kepala-kepala suku dan ulama yang dipandang layak dan mumpuni. Lihat Achmad Syahid, Pemikiran Politik, h. 249

${ }^{44}$ Lihat Mushthafâ Al-Khin, Al-Fiqh AlManbaji 'Alâ Madz̧hab Al-Imâm Asy-Syâfi't, (Serbia: al-Fithrah, tt), jilid 3, h. 610-611. Wahbah AzZuhaili, Al-Fiqh Al-Islâmî, juz. 6, h. 680-683 bai'at ablil halli wal 'aqdi. Ablul $\underline{H}$ alli Wal 'aqdi adalah sebuah institusi politik yang memiliki wewenang melantik raja setelah sebelumnya menggelar musyawarah untuk menentukan sosok figur yang dipandang layak dan memenuhi kriteria dan prasyarat untuk dinobatkan menjadi raja. Adapun komposisi ablul halli wal aqdi terdiri atas beberapa orang laki-laki yang adil dan memiliki reputasi yang baik, kepala-kepala suku dan ulama yang dipandang layak dan mumpuni.

Hasil musyawarah dan pelantikan yang dilakukan oleh ablul balli wal aqdi secara otomatis memberikan wewenang kepada raja yang dilantik untuk mengemban tugas menegakkan kebenaran (baq) dan menjauhkan kelaliman berdasarkan lunas-lunas syari'at dan berkuasa atas seluruh wilayah kerajaan berikut wilayah-wilayah taklukan beserta semua pihak yang berdiam didalamnya. Namun sayangnya, Raja Ali Haji tidak sama sekali menyinggung tentang hal yang dianggap urgent oleh para fuqaha ${ }^{45}$, yaitu masalah kuorum $^{46}$ pada majelis

${ }^{45}$ Para fuqaha berpendapat karena implikasi bai'at itu mengikat seluruh pihak yang berada pada wilayah kekuasaan raja tersebut untuk taat kepadanya, dan merupakan bentuk penegasan penerimaan terhadap kepemimipinan sang raja maka masalah kuorum menjadi penting. Hal ini menjadi pendapat Al-Asy'ari, Al-Baqillani, AlQalani, Al-Ghazâli, Al-Juwaini, Al-Syihristani. Lihat: Syahid, Pemikiran Politik, h. 250

${ }^{46}$ Sebagian fuqaha berpendapat bahwa kuorum baru tercapai hanya dengan kehadiran mayoritas anggota Ablul $\underline{H}$ alli wal 'Aqdi. Namun pendapat ini terbantahkan dengan sendirinya dengan kondisi faktual bai'at Abu Bakar As-siddiq. Fuqaha Kufah berpendapat kuorum tercapai dengan 3 orang dengan analogi akad nikah; 1 hakim, 2 saksi. Sebagian besar fuqaha berpendapat bahwa kuorum dapat tercapai dengan 5 orang anggota Ablul Halli wal 'Aqdi dengan argumen bai'at Abu Bakar As-siddiq oleh 5 orang (Umar, Abu Ubaidah ibn Al-Jarrah, Usaid ibn hudhair, Basyr ibn Sa'ad, dan Salim maula Abi Hudzaifah). Ada juga yang berpendapat cukup dengan satu orang saja, dengan argumen bai'at Al-'Abbas kepada Ali ibn Abi Thalib. Lihat: Ali bin 
musyawarah ablil halli wal 'aqdi, siapa yang paling berhak melantik diantara mereka, ${ }^{47}$ dan perlunya saksi saat prosesi pelantikan dilakukan oleh mereka.

Sebab kedua seseorang menjadi raja menurut Raja Ali Haji adalah istikblâf yakni menjadikan satu raja akan gantinya masa hidupnya, pada yang patut menjadi $\mathrm{Raja}^{48}$ yaitu sebuah mekanisme yang dilakukan oleh seorang raja (pemimpin) yang sedang berkuasa untuk menunjuk seseorang yang akan menggantikan dirinya. Keabsahan mekanisme istikhlaf ini berdasarkan ijmâ atau konsensus umat. ${ }^{49}$ Bukti empirik mekanisme istikblâf ini adalah apa yang dilakukan oleh Abû Bakar as-Siddîq saat masih menjabat sebagai khalifah yang menunjuk 'Umar bin Khathâb menjadi penggantinya. Adapun bentuk konsensus umat terhadap mekanisme ini adalah praktek Abû Bakar as-Siddîq dan tidak adanya penolakan ummat atas diberlakukannya mekanisme ini.

Namun, Raja Ali Haji tampaknya mengalami iltibâs dalam menyebutkan contoh mekanisme istikhlâf ini. Dalam persepsi Raja Ali haji contoh dari istikblâf adalah musyawarah yang ditempuh oleh keenam $^{50}$ calon yang ditunjukknya untuk

Muhammad bin Habîb Al-Mâwardi, Al-Abkeâm AsSulthâniyyah, h. 7

${ }^{47}$ Al-Ghazâli berpendapat bahwa yang paling berhak untuk melantik raja dari kalangan ablul halli wal 'aqdi adalah dzu syaukah atau orang yang paling berwenang karena paling mendapat banyak dukungan dari rakyat. Hal ini menurutnya hal ini akan membuat pihak lain akan segera membaiat raja tersebut dan inqiyâd (taat) kepadanya karena tujuan bai'at ini adalah meyatukan berbagai pendapat dan keinginan kepada seorang raja yang ditaati bersama atau agar kepemimipinan berjalan efektif.

${ }^{48}$ Raja Ali Haji, Tsamarat Al- Muhimmah, dalam Mahdini, Tsamarât Al-Mubimmah, h. 43

${ }^{49} \mathrm{Ali}$ bin Muhammad bin Habîb AlMâwardi, Al-A hlkâm As-Sulthâniyyah, h 11

${ }^{50}$ Mereka ini adalah 'Usmân bin 'Affân, 'Alî bin Abî Thâlib, Az- Zubair bin 'Awwâm, 'Abdurrahmân bin 'Auf, Sa'ad bin Abi Waqqâsh, dan Thalhah bin 'Ubaidillâh. memilih salah satu diantara mereka sendiri sebagai khalifah suksesor 'Umar bin Khathâb. Padahal lintasan sejarah yang diperankan oleh mereka dalam fase itu adalah sebuah mekanisme ablul balli wal 'aqdi yang menurut Syahid disebut sebagai preseden terbaik bagi penerapan lembaga ablul balli wal 'aqdi'

Pada tataran praktisnya, Kerajaan Riau-Lingga yang menganut konsep politik kerajaan atau monark $b i$ mendasarkan suksesi kepemimpinan kerajaan melalui mekanisme istikblâf, yaitu para suksesor pengganti Sultan (Yang Dipertuan Muda Riau) Riau-Lingga dipilih oleh Sultan yang sedang berkuasa setelah berkonsultasi terlebih dahulu dengan keluarga kerajaan ataupun pihak-pihak yauy terkait dengan masalah tersebut. ${ }^{52}$

Adapun sebab ketiga seseorang menjadi raja menurut Raja Ali Haji adalah dengan cara taghallub atau penguasaan dengan kekuatan dan kemenangan. Meskipun Raja Ali Haji tidak membahas mekanisme taghallub ini secara terperinci. Substansi peralihan kekuasaan dengan mekanisme ini terjadi apabila ada seorang laki-laki yang melakukan invasi militer dan memenangkan pertempuran kemudian menobatkan dirinya sebagai raja, maka sahlah kepemimpinannya tersebut tanpa diperlukan akad pada saat yang sama umat Islam harus mengakui keabsahan kepemimpinannya.

$\mathrm{Hal}$ ini sebagaimana riwayat Abu Ya'la dari Ibnu Malik al-'ath-thâr sebagai berikut:

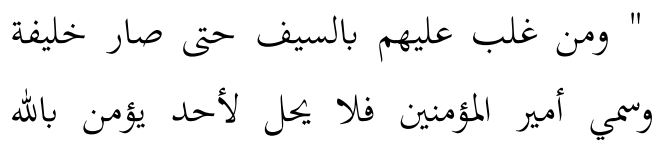

\footnotetext{
51 Achmad Syahid, Pemikiran Politik, h. 252

${ }^{52}$ Raja Ahmad dan Raja Ali Haji, Tubfat AnNâfis, h. 353-355
} 


\section{واليوم الآخر أن يبيت ولا يراه إماماً، براً كان أو

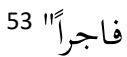 \\ "Dan barangsiapa mengalabkan mereka (penguasa sebelumnya) dengan kekuatan pedang, sehingga menjadikan dirinya khalifah dan diberi gelar amir al-mukminin, maka tidak halal bagi seorang yang beriman kepada Allah dan hari akbir untuk tidak mengakuinya sebagai imam, baik bersikap baik maupun jahat."}

b) Makna Raja

Sebagai pemegang tertinggi supremasi kekuasaan, seorang raja hendaknya menjadi sosok ideal yang memiliki karakteristik komplit dan menunjukkan kredibilitas (mishdaqiyah) untuk menunaikan amanah besar yang dipikulkan di pundaknya. Raja hendaknya dapat menjadi panutan bagi rakyatnya, pada saat yang sama juga harus merakyat dalam artian mengerti betul dan merasakan kondisi riil rakyatnya.

Terkait dengan peran yang harus dimainkan seorang raja, Raja Ali Haji memberikan pandangan politiknya sebagai berikut:

"Bermula makna raja itu, jika dikata raja itu dengan makna khalifah yaitu khalifah Rasulullah Shal-lallabu 'alaibi wasallam, pada mendirikan Islam dan menghukumkan akan segala hamba Allah dengan hukumnya Qur'an dan hadits dan ijma`.

Jika dikata raja itu dengan makna sultan, maka yang mengeraskan hukuman atas segala rakyatnya dengan hukuman yang adil yang datang daripada Allah dan RasulNya.

Dan jika dikata raja itu dengan makna imâm, maka yaitu ikutan segala rakyatnya yang tiada membawa kepada kufur dan maksiat."

Dalam pemikiran politik Raja Ali Haji, pada hakikatnya seorang pemimpin, dalam hal ini adalah raja, setidak-tidaknya

53 Abû Ya'la Muhammad ibn Husain AlFarrâ', Al-Ahkầm As-Sulthâniyyah, h. 23 harus mampu merepresentasikan tiga tipikal kepemimpinan sekaligus sehingga keberadaannya dapat menghadirkan kemaslahatan yang optimal bagi ra'iyyah serta meminimalisir bahkan menegasikan mafsadah.

Tiga tipikal kepemimpinan yang harus diperankan seorang raja atau pemimpin tersebut adalah: pertama, (raja) merepresentasikan eksistensi seorang khalîfah. Maksudnya raja sebagai "wakil" Tuhan di muka pemimpin bumi untuk memakmurkan bumi dengan syariat-Nya sekaligus "wakil" Nabi Muhammad, sebagai penerus estafeta kepemimpinan dalam penegakan Islam dan implementasi hukum-hukumnya. Dengan kata lain fungsi pemimpin atau dalam hal ini raja adalah membumikan syariat dan risalah kenabian yang telah dibawa oleh Nabi Muhammad SAW atau al-khilâfah 'alâ minhâj an-nubuwwah.

Kedua, pemimpin (raja) merepresentasikan eksistensi seorang sulthân. Yaitu bahwasanya raja dengan legitimasi politik berupa kepercayaan dari rakyat yang diberikan kepadanya berkewajiban untuk menghadirkan kemaslahatan yang optimal bagi ra'iyyah serta meminimalisir mafsadah. Oleh karena itu, pemimpin (raja) harus menjalankan roda pemerintahan dalam koridor menegakkan keadilan sesuai dengan petunjuk Al-Qur'an dan al-Sunnah.

Ketiga, pemimpin (raja) merepresentasikan peran seorang imâm. maksudnya ia harus menjadi suri tauladan dan pilot project bagi rakyatnya. Analoginya adalah imam shalat, yang setiap perbuatannya harus diikuti oleh makmum. Sebagaimana hadits Rasulullah:

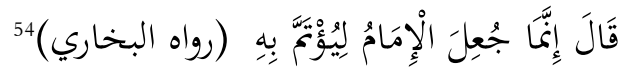

54 Hadits Riwayat Al-Bukhari, dengan sanad sebagai berikut:

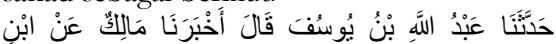

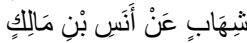


"Sesunggubnya Imam itu banya diangkat untuk diikuti” (HR. Muslim)

Satu hal yang cukup mengejutkan menurut Syahid, ${ }^{55}$ adalah karena Raja Ali Haji tidak menyinggung terminologi amir yang harus terepresentasikan oleh raja, padahal istilah ini dipergunakan oleh Umar bin Khattab dengan gelar amir almu'minin. ${ }^{56}$

\section{c) Kriteria Raja}

Sebagaimana bahasan para fuqaha, Raja Ali Haji juga meletakkan prasyarat dan kriteria yang cukup ketat yang harus dipenuhi seorang raja. Pemberian kualifikasi yang ketat terhadap calon raja ini juga dibahas oleh para fuqaha klasik. Hal ini merupakan sebuah ikhtiar dari mereka agar calon raja tersebut benarbenar qualified sehingga mampu mengemban amanah kepemimpinan tersebut dengan baik.

Dalam hal ini ia menyatakan:

"Adapun syaratnya 'ala al-jumlah bahwa hendaklah raja itu Islam yang teguh memegang ugama Islam dan laki-laki mukallaf dan merdeka lagi adil lagi mempunyai ijtihad yang elok dan mempunyai bicara yang baik dan penglihatan yang baik dan mempunyai berani yang tetap dan yang rajin, tiada jemu dan malas daripada mendirikan kerajaan, lagi pantas segera berbangkit pada tiap-tiap pekerjaan yang jadi kebijakan, maka inilah setengah syarat raja yang dihimpunkan". ${ }^{57}$

Dalam hal ini dapat dijabarkan bahwa kualifikasi calon raja menurut Raja Ali haji adalah:

1) Beragama Islam dan komotmen menjalankan ajarannya;

2) Laki-laki mukallaf yang merdeka;

\footnotetext{
${ }^{55}$ Achmad Syahid, Pemikiran, h. 34

56 Ali bin Muhammad bin Habîb AlMâwardi, Al-A $\underline{b} k$ âm As-Sulthâniyyah, h. 13

${ }^{57}$ Raja Ali Haji, Tsamarat Al- Muhimmah, dalam Mahdini, Tsamarât Al-Mubimmah, h. 44
}

3) Adil;

4) Memiliki kemampuan untuk berijtihad yang baik;

5) Memiliki kemampuan berbicara yang baik;

6) Memiliki kemampuan mendengar yang baik;

7) Memiliki keberanian yang tetap;

8) Rajin dan tidak malas dalam menjalankan roda pemerintahan;

9) Trengginas dan cekatan dalam melakukan pekerjaan yang mengarah kepada kebajikan.

Secara umum, pandangan Raja Ali Haji ini inline dengan pendapat para fuqaha. sebut misalnya Al-Mâwardi yang mempersyaratkan 7 kriteria bagi seorang imam, yaitu: adil, berilmu yang memungkinkan untuk berijtihad, sehat indera pendengaran, penglihatan dan lisannya, sehat secara fisik yang memungkinnya untuk cepat bergerak dan cekatan, kecerdasan yang dapat mengatur kemaslahatan rakyat, berani dalam melindungi negeri dan berjihad melawan musuh, serta keturunan dari suku Quraisy. ${ }^{58}$ Hanya saja Raja Ali Haji tidak menyebutkan syarat terakhir yang disebutkan Al-Mâwardi, yaitu keturunan dari suku Quraisy.

Dalam hal ini Syahid menulis:

"Agak mengejutkan mengapa Raja Ali Haji 'membuang' syarat kepemimpinan dari suku Quraisy, padahal isu ini telah menjadi polemik para teolog faqih dalam diskusi panjang merekayang mengupas masalah syarat-syarat menjadi pemimipin negara. Apalagi, kitab Fath AlWahhâb karya Al-Anshâri yang dijadikan kitab matan bagi Raja Ali Haji masih mempertahankan klausul itu sebagai syarat menjadi raja.. ${ }^{59}$

Tetapi, menurut hemat peneliti, penanggalan syarat 'keturunan dari suku Quraisy' oleh Raja Ali Haji dalam kitab

58 Ali bin Muhammad bin Habîb AlMâwardi, Al-Ablkâm As-Sulthâniyyah, h. 693-697

59 Achmad Syahid, Pemikiran Politik, h. 258 
Tsamarât Al-Mubimmah ini dikarenakan kitab Tsamarât Al-Mubimmah ini bukan hanya sekedar karya ilmiah di bidang fikih siyasah an sich melainkan juga sebagai pedoman yang secara faktual diberlakukan di dalam lingkup entitas kerajaan RiauLingga yang tentu saja 'tidak membutuhkan' syarat keturunan dari suku Quraisy. Dan hal ini yang menjadi diferensiasi antara karya Raja Ali Haji dengan karya-karya fuqaha klasik pendahulunya, meskipun tampak terlihat Raja Ali Haji mengambil dan mensarikan teori politiknya dari pendapat-pendapat mereka.

d) Hak dan Kewajiban Raja

Ketika tata cara pendirian raja telah sah dan prasyarat yang menjadi kriteria seorang raja terpenuhi maka, sang raja tersebut memiliki hak yang sifatnya given dari syarak yang sekaligus menjadi kewajiban rakyat yang dipimpinnya.

Dalam hal ini Raja Ali Haji menyatakan:

"Syahdan apabila didapat jalan dan makna dan isyarat yang terdapat itu atas suatu orang yang telab menjadi raja, maka fardulah atas segala rakyat tentaranya taat akan dia, dan haramlah atas segala rakyat melalui titah perintahnya yang tiada membawa kepada kufur dan maksiat dan jika melalui perintah rajanya serta tiada didengarnya perintah rajanya itu maka jadilah ia orang durbaka. Dan jika rakyat-rakyat itu berkumpul kepada satu tempat dengan menungukubkan tempatnya pada melawan raja, maka yaitu dinamakan ia orang bugat, yakni orang durbaka. Dan berlakulah bukum bugat atas mereka itu. Seperti yang tersebut didalam kitab fikih dengan harus memerangi mereka itu dengan syaratnya, intaha”. ${ }^{00}$

Adapun hak yang diberikan syarak kepada sang raja yang sah yang pada saat yang sama menjadi kewajiban rakyat yang dipimpinnya adalah ditaati titah-titahnya.

${ }^{60}$ Raja Ali Haji, Tsamarat Al- Muhimmah, dalam Mahdini, Tsamarât Al-Mubimmah, h. 45-46
Menurut Al-Mâwardi hak raja atas rakyatnya ada dua hal, yaitu ath-thâ'ah wa an-nushrah (ditaati dan dibantu dalam pencapaian target-target tugasnya $)^{61}$. Akan tetapi, dalam lintasan sejarah kita dapatkan satu hak lain yang diperoleh imam, yaitu hak memperoleh imbalan dari harta baitul mal untuk memenuhi keperluan hidudnya dan keluarganya secara patut. ${ }^{62}$

Terkait dengan hak pemerintahan yang sah yang telah menunaikan kewajibannya, Hasan Al-Banna menambahkan al-walâ (loyalitas) rakyat kepada pemerintah disamping taat dan menolong atau membantu pemerintah. ${ }^{63}$

Adapun karakter dari pemerintahan yang layak untuk mendapatkan loyalitas, sikap taat dan bantuan dengan harta dan jiwa dari rakyat menurut Hasan Al-Banna adalah pemerintahan yang memiliki sikap tanggungjawab dan perhatian terhadap rakyat, berlaku adil kepada semua manusia, menjaga diri (iffah) dalam mendayagunakan harta kekayaan rakyat (asset negara), serta efektif dan ekonomis dalam penggunaannya. ${ }^{64}$

Terkait dengan kontribusi terhadap negara dan membantu tugas-tugas raja ini, di dalam Gurindam Dua Belas pasal 11, Raja Ali Haji mengungkapkan:

\footnotetext{
${ }^{61} \mathrm{Al}$-Mâwardi, Al-Ahkâm As-Sulthâniyyah, h. 19.

${ }^{62} \mathrm{Hak}$ atas gaji ini dapat kita temukan dalam masa kekhalifahan Abu Bakar, yaitu diriwayatkan sampai 6 bulan semenjak diangkat menjadi khalifah, Abu Bakar masih berniaga di pasar untuk menafkahi diri dan keluarganya. Karenanya para sahabat bermusyawarah terkait pemenuhan nafkah tersebut, karena dengan tugas beratnya sebagai khalifah tentu menyulitkan beliau untuk tetap berniaga, sehingga diputuskan untuk memberikan gaji sebesar 6000 dirham setahun. Lihat Abdul Qadir Audah, Al-Islâm wa Audhâ'una Al-Siyâsiyyah, (Kairo: Dar al-kitâb al-'arabi, 1957), h. 189

${ }^{63}$ Hasan Al-Banna, Kumpulan Risalab Dakwah Hasan Al-Banna, (Jakarta: Al-I'tishom, 2007), Jilid 1, h. 305

${ }^{64}$ Ibid, h. 304
} 


\section{bendaklah berjasa}

kepada yang sebangsa ${ }^{65}$

Secara umum dua larik gurindam tersebut memerintahkan kepada setiap pihak yang berada dalam komunitas masyarakat, baik berposisi sebagai yang memimpin maupun yang dipimpin (rakyat) untuk berkiprah dalam menebar jasa dan kebaikan dalam lingkungan masyarakat untuk mencapai tujuan bersama.

Dalam kerangka taat dan berkontribusi tersebut, rakyat dan terutama para pejabat kerajaan tetaplah harus kritis terhadap setiap policy yang diambil oleh sang raja, karena sikap tunduk tanpa dibarengi sikap kritis akan berimplikasi pada kinerja yang asal-asalan yang pada gilirannya tidak akan membawa kepada pencapaian visi dan target-target sang raja itu sendiri. Hal ini diungkapkan Raja Ali Haji dalam pasal ke dua belas gurindamnya, yaitu:

\section{betul hati kepada raja \\ tanda jadi sebarang kerja ${ }^{66}$}

Selanjutnya Raja Ali Haji membahas tentang hukum mendurhakai titah raja yang sah dan telah melaksanakan kewajibannya, sebagai berikut:

“....dan jika melalui perintah rajanya serta tiada didengarnya perintah rajanya itu maka jadilah ia orang durhaka. Dan jika rakyat-rakyat itu berkumpul kepada satu tempat dengan menungukuhkan tempatnya pada melawan raja, maka yaitu dinamakan ia orang bugat, yakni orang durhaka. Dan

${ }^{65}$ Raja Ali Haji, Gurindam Dua Belas, dalam Abu Hassan Sham, Puisi-puisi Raja Ali Haji, (Kuala Lumpur: Percetakan Dewan Bahasa, h. 282

${ }^{66}$ Frasa 'betul hati' bermakna tunduk dan tidak kritis. Sedangkan Frasa 'sebarang kerja' bermakna kerja asal-asalan. Secara umum makna penggalan pasal ke 12 dari gurindam dua belas adalah dalam melakukan pekerjaan harus bersikap kritis agar beroleh hasil yang baik. Lihat Ahmad Badrun, Gurindam Dua Belas: Sebuah Pertemuan Dengan Raja Ali Haji, Makalah ditulis atas undangan Pemerintah Kota Tanjungpinang dalam rangka pengusulan Raja Ali Haji sebagai Pahlawan Nasional dan terkodifikasi dalam buku Sejarah Perjuangan Raja Ali Haji Sebagai Bapak Bahasa Indonesia . Lihat: Hasan Junus, Sejarah Perjuangan Raja Ali Haji, h. 403. Lihat juga Raja Ali Haji, Gurindam Dua Belas, dalam Abu Hassan Sham, Puisi-puisi Raja Ali Haji, h. 282 berlakulah hukum bugat atas mereka itu. Seperti yang tersebut didalam kitab fikih dengan harus memerangi mereka itu dengan syaratnya" 67

Menurut Raja Ali Haji, perbuatan anti taat dan tidak mendengar perintah raja tergolong perbuatan durhaka, karena menyalahi perintah Allah dan RasulNya. ${ }^{6}$ adapun jika perbuatan durhaka ini dilakukan secara komunal, yakni sekumpulan orang yang berkumpul pada suatu tempat tertentu dalam rangka untuk melawan titah raja, maka dalam terminologi syariah perbuatan mereka disebut dengan al-baghy $u^{69}$ sedangkan para pelakunya disebut bughat.

Ada satu catatan yang diberikan jumbur ulama terkait perlakuan terhadap abl al-bughât yang diperangi tersebut, yaitu bahwa harta benda yang mereka tinggalkan tidak boleh dirampas, tetapi dipelihara pemerintah untuk kemudian dikembalikan kepada pemiliknya yang masih hidup ketika mereka sudah sadar dan diberikan kepada ahli warisnya sekiranya mereka terbunuh dalam perang penumpasan pemberontakan tersebut. ${ }^{70}$

Hasbi Ash-Shiddieqy berpendapat bahwa diantara al-nushrah (pertolongan) yang harus diberikan kepada kepala negara adalah membantu dan mempertahankannya apabila ditangani oleh kaum pemberontak, karena

${ }^{67}$ Raja Ali Haji, Tsamarat Al- Muhimmah, dalam Mahdini, Tsamarât Al-Mubimmah, h. 45-46

${ }^{68}$ Lihat QS. An-Nisa [4]:59 serta haditshadits terkait perintah taat dan koridor ketaatan yang disebutkan Rasulullah.

${ }^{69}$ Secara etimologis al-baghyu berasal dari تجاوز الحد واعتدى yang bermakna بغى kalimat melampaui batas dan sewenang-wenang. Lihat: Ibrahim Unais, Al-Mu'jam Al-Wasith, tt, h. 85. Dalam hukum pidana Islam berarti pemberontakan terhadap pemerintahan yang sah dan berdaulat. Ulama Malikiyah mendefinisikannya sebagai sikap tidak mau tunduk kepada penguasa atau pemimpin yangg diangkat secara sah dengan cara demonstratif, sedangkan pemimpin tersebut tidak menyuruh mereka berbuat maksiat. Ulama Ahnâf mencontohkan prilaku al-baghyu ini dengan menyebut golongan khawarij yang keluar dari kepemimpinan Ali bin Abi thalib karena tidak setuju dengan arbitrase yang dilakukannya dengan Muawiyah bin Abi Sufyan. Lihat: Abdul Aziz Dahlan, Ensiklopedi Hukum Islam, (Jakarta: Ichtiar Baru Van Hoeve, 1996), jilid 1, h. 172

${ }^{70} \mathrm{Ibid}$, h. 173-174 
mereka hakikatnya memecahbelah rakyat dan menimbulkan bencana bagi rakyat dan negara. ${ }^{71}$

\section{e. Pemakzulan Raja}

Dalam paradigma politik Islam, jabatan kepala negara bukanlah sesuatu yang absolut dan sakral, kepala negara hanyalah mandataris ummat, atau lebih tepat pelayan mereka. mandat tersebut bisa dicabut jika memang diperlukan dan jika pemegang mandat mengabaikan amanah, kewajiban, dan tanggungjawabnya. Oleh karena itu, para ulama menuliskan bab khusus tentang ' $A$ zlu as-sulthân (pelengseran kepala negara) dalam kitab-kitab figh sijâsah. Dalam hal ini meskipun dengan sangat hati-hati Raja Ali Haji juga mengikuti jalan mereka.

“ Sebermula adapun Imam al-a'₹ham yakni sultan, tiada boleh diturunkan dari pada kerajaan jika hilang sifat adilnya sekalipun. Inilah yang tersebut di dalam matan kitab Jaubarah at-Taubîd dengan katanya, "falaisa yu'ralu an yazula washfahu" yakni tiada boleh diturunkan raja itu dari pada kerajaannya jika hilang sifat 'adalahnya sekalipun. Kemudian maka meistisnakan pula dengan katanya, "illa bikufrin fantabidzna 'abdabu" yakni melainkan jika ia kufur berpaling dari pada agama atau menghalalkan yang haram dan 'aksunya yang membawa kepada kufur, maka yaitu kita lepaskanlah janjinya, yakni tiadalah harus kita berajakan dia.

"Akan tetapi tersebut di dalam syarah Jaubarah at-Taubid yaitu Ithâf al-Murid serta syarahnya beberapa thaifah ulama seperti Syafi'i sekira-kira mengata mereka itu, "tiada boleh diturunkan raja itu dari pada kerajaannya dengan sebab jahat dan fasik. Akan tetapi harus diganti dengan lainnya jika tiada hasil dengan demikian itu fitnah dan harus pula turun dari pada kerajaannya (jika) lemah dari pada mashalih al muslimin yakni lemah ia dari pada membaiki orang yang muslimin yang di bawah takluk kerajaannya dan harus pula turun dari pada kerajaannya dengan sebab tertawan musuhnya yang tiada harap akan lepasnya. Dan demikian lagi harus turun dari pada kerajaannya jika ia gila yang

${ }^{71} \mathrm{Hasbi}$ Ash-Shiddieqy, Ilmu Kenegaraan Dalam Fikih Islam, Jakarta: PT. Bulan Bintang, 1991, h. 11. muthabaqah atau buta atau tuli dan bisu. Dan apabila diperolehnya segala sifat yang tersebut itu haruslah ia minta ganti kepada siapa-siapa yang patut akan gantinya." Inilah hukum yang tersebut dalam kitab syarah kitab Ithâf alMurid." Intaha. ${ }^{72}$

Oleh karena kekuasaan dalam Islam adalah amanah yang harus dipertanggungjawabkan, maka raja ataupun pemimpin harus bertanggungjawab atas apa yang diamanahkan kepadanya. Dalam Islam, seorang raja atau pemimpin harus mempertanggungjawabkan amanahnya di hadapan rakyat dan juga di hadapan tuhan. Pertanggungjawaban dihadapan rakyat adalah karena rakyatlah yang memberikan hak memerintah dan mengendalikan kekuasaan kepadanya, karenanya rakyat berhak memberikan bai'at, meminta pertanggungjawaban, serta berhak pula untuk memakzulkannya ${ }^{73}$ jika diperoleh sebab-sebab untuk itu. ${ }^{74}$

Dalam membahas persoalan suksesi kepemimpinan yang merupakan persoalan sensitif, Raja Ali Haji terlihat sangat hati-hati dalam membahasnya, sehingga ia membahasnya bersama dengan bahasan tentang mekanisme pemakzulan pejabat tinggi kerajaan. Menurut Syahid, prinsip kehatihatian ini merupakan tipikal umum ulama $A b l$ al-Sunnab wa al-Jamâ'ab dari kalangan Syâfi'izyab. ${ }^{75}$

Raja Ali Haji berpendapat bahwa raja tidak boleh dimakzulkan sekalipun sifat 'adâlabnya telah hilang dari dirinya, berubah menjadi jahat dan fâsik. Raja Ali Haji mengutip pendapat Ibrâhim bin Ibrâhim bin Hasan Al-Laqâni yang mengungkapkan pendapatnya dengan ungkapan "falaisa yu' zalu an yazûla washfahu" yakni seorang raja tidak boleh diturunkan dari kerajaannya meskipun hilang sifat ('adâlahnya) sekalipun.

${ }^{72}$ Raja Ali Haji, Tsamarat Al- Muhimmah, dalam Mahdini, Tsamarât Al-Mubimmah, h. 51

${ }^{73}$ Pemakzulan ini dapat dilakukan setelah mekanisme al-nushu wa al-irsyad (menasehati dan menunjukkan perbuatan salahnya serta mengarahkan kepada yang sepatutnya dilakukan). Lihat: Hasan Al-Banna, Kumpulan Risalab Dakwah, h. 305

${ }^{74}$ Hasbi Ash-Shiddieqy, Ilmu Kenegaraan, h. 118

${ }^{75}$ Achmad Syahid, Pemikiran Politik, h. 260 
Akan tetapi, seorang raja dapat dimakzulkan jika telah memenuhi syaratsyarat berikut: Pertama, kafir. "illa bikufrin fantabidzূna 'ahdabu' yakni melainkan jika ia kufur berpaling dari agama Islam, baik dari perkataan maupun perbuatannya. Raja Ali Haji mencontohkan tindakan kufur ini adalah menghalalkan yang haram dan mengharamkan yang halal, karena hal itu akan berimplikasi kepada kekufuran pelakunya.

Kedua, lemah dalam mengurus mashâlih al muslimin, yakni mengoptimalkan kemaslahatan bagi kaum muslimin yang berada di bawah kekuasaannya. Ketiga, berada dalam tawanan musuh yang tidak tidak ada kepastian akan pembebasannya sehingga menghalanginya untuk melaksanakan tugastugas kenegaraan. Keempat, kehilangan akal sehatnya (gila) secara permanen. Kelima, cacat yang permanen, buta, tuli, dan bisu. Dalam kondisi syarat-syarat tersebut diatas terpenuhi, maka rakyat boleh melepaskan akad kesetiaan kepada raja tersebut dan menggantinya dengan figur yang layak dan memenuhi kualifikasi seperti yang telah disebutkan sebelumnya.

Secara umum, pendapat Raja Ali Haji ini tergolong relatif longgar ${ }^{76}$, mungkin

\footnotetext{
${ }^{76}$ Kesan longgar ini terlihat ketika Raja Ali haji mengikuti pendapat Al-Laqani yaitu seorang raja tidak boleh diturunkan dari kerajaannya meskipun hilang sifat ('adalabnya) sekalipun. Bandingkan dengan pendapat Al-Syafi'i yang mengatakan: "Kepala negara terpecat dengan kefasikan dan kecurangan. Demikian pula qadli dan amir." Lihat Hasbi Ash-Shiddieqy, Ilmu Kenegaraan, h. 118. Atau Al-Mâwardi yang berpendapat bahwa cacat/berkurang keadilan kepala negara dan cacat fisik (naqs $f i$ badanib) sebagai alasan untuk mengeluarkan imam dari jabatannya. Lihat AlMâwardi, Al-Ab̆kâm Al-Sulthâniyyah, h. 19. Atau Al-Ghazâli yang merupakan inspiratornya yang berpendapat: Sultan yang zhalim wajib menghentikan kekuasaannya dan dia adakalanya terpecat atau dipecat, dan dia sama sekali bukan lagi penguasa. Lihat: Hasbi Ash-Shiddieqy, Ilmu Kenegaraan, h. 119, atau pendapat al-Razi: "orang yang dzalim tidak dapat dipercayakan terhadap perintah-perintah Allah dan bukan orang yang menjadi teladan. Karena itu mereka tidak bisa menjadi kepala dalam agama. Maka dengan petunjuk ayat, nyatalah kebatalan kekuasaan orang fasik." Lihat: Hasbi Ash-Shiddieqy, Imu Kenegaraan, h. 120.
}

dikarenakan sistem monarkhi yang dianut dalam perpolitikan saat itu memang sangat memungkinkan dilakukan peralihan kekuasaan. Akan tetapi, Raja Ali Haji tetap memberikan warning akan munculnya fitnah, jika terjadi pemakzulan raja tanpa terpenuhinya syarat-syarat diatas.

\section{KLASIFIKASI CORAK PEMIKIRAN POLITIK ISLAM}

Sebagai bagian integral dari sistem Islam, maka pemikiran politik Islam tidak dapat dipisahkan dari pemikiran aspekaspek lainnya yang inhern dengan pemikiran Islam, seperti aspek kalam dari mutakallimin (ahli kalam), fikih dari fuqaha (ahli fiqih), bahkan tasawuf dari kalangan sufi. Hal ini menurut Imam Sukardi, berakibat pada lahirnya beberapa corak pemikiran ketatanegaraan dalam Islam, yang secara garis besar dapat dikategorikan ke dalam beberapa corak pemikiran, antara lain: corak filsafat, corak hukum, corak birokrasi, dan corak etik. ${ }^{77}$

Corak filosofis adalah suatu corak pemikiran kenegaraan yang mencoba menawarkan sebuah kerangka ideal dari sebuah pemerintahan Islam yang ditandai dengan kemunculan konsep negara ideal yang digagas oleh Al-Farabi dalam kitab Al-Madinah Al-fadbilah. Al-Farabi mendefinisikan negara utama sebagai suatu negara dengan pemerintahan dan rajyat bergotong royong membangun pribadi mereka masing-masing menjadi manusia utama sehingga dapat menampilkan karya-karya mulia dalam rangka mencapai kebahagiaan. Akar dan sumber pemikiran ini berasal dari akumulasi teori-teori filsafat Yunani dan Islam yang dikembangkan oleh para filsuf muslim seperti Al-Farabi dan Ibnu Sina. ${ }^{78}$

Adapun corak hukum adalah suatu corak pemikiran politik yang mengemukakan teori-teori yang berfokus pada teori legitimasi dan sudut pandang

\footnotetext{
${ }^{77}$ Imam Sukardi, Pemikiran Politik Al-Farabi (Diskursus Kepemimpinan Negara), hal. 6

${ }^{78}$ Ibid, h. 6-7
} 
yang digunakan adalah hukum Islam. Sehingga objek pemikiran ditentukan menurut sudut pandang fiqih. Diantara penggagas corak ini adalah fuqaha' almadhabib tertentu seperti Al-Mawardi dari kalangan Syafi'iyyah, Abu Ya'la Ibnu Farra' dari kalangan Malikiyyah, Ibnu Taimiyah dari kalangan Hanabilah, dan Ibn Jama'ah. Fokus pemikiran corak hukum ini tertuju pada teori pemerintahan (khilafah) yang menyejarah dengan suatu penekanan yang sangat formal dan kaku, mejadi isntitusi keagamaan sekaligus institusi politik yang harus dilestarikan. Mereka mengelaborasi nash-nash AlQur'an tentang permusyawaratan serta mengenalkan konsep abul Halli wa Al-aqdi dalam rangka melegitimasi kekuasaan khalifah. $^{79}$

Kemudian corak birokrasi adalah corak pemikiran politik yang menguraikan tentang konsekuensi logis dari perluasan kekuasaan Islam terutama setelah periode kekuasaan kbulafa al-rasyidin, maka baik pemerintahan Dinasti Bani Umayyah maupun Dinasti Abbasiyyah banyak membutuhkan tenaga administrasi untuk menjalankan mekanisme pemerintahan. Kekurang-cakapan dan kekurangterampilan bangsa Arab dalam lapangan ini menyebabkan banyak orang-orang persia yang telah masuk Islam diminta untuk menduduki posisi administratif tersebut. Selanjutnya mereka menyusun teori-teori politik administrasi negara yang diambil dari khazanah warisan pra-Islam Iran. Karya-karya ini disusun dalam bahasa Persia meskipun kala itu bahasa Arab telah menjadi bahasa dunia Islam. Dari sisi konten, karya-karya tersebut secara garis besar membahas struktur dan hirarki pemerintahan. ${ }^{80}$

Adapun corak etik muncul dan dipelopori oleh Al-Ghazali dalam karyanya Nashibat Al-Muluk yang merupakan persembahan bagi Sultan

${ }^{79}$ Ibid, h. 7

${ }^{80}$ Ibid, h.8
Saljuk, Muhammad Malik Syah. AlGhazali menegaskan bahwa sultan (penguasa) mempunyai kedudukan sebagai bayangan tuhan di muka bumi (Zhillullah fi Al-Ardh) karena semua rakyat harus tunduk dan taat. Bahkan dalam Kimiya'i Al-Sa'adah Al-Ghazali dengan tegas menginterpretasikan terma ulul amri yang terdapat dalam Q.S. Al-Nisa' ayat 58 sebagai amir, yaitu jabatan dengan kekuasaan tertinggi pada masa Dinasti saljuk. $^{81}$

\section{KESIMPULAN}

Secara umum pemikiran politik Raja Ali Haji sebagaimana yang termaktub dalam karya-karya monumentalnya sangat mendukung pendapat para ulama sunni, terutama Hujjatul Islam Al-Imam AlGhazali dan juga Imam Al-Mawardi. Warna kitab Nasibatul muluk dalam pemikiran Al-Ghazali begitu kental terasa terutama dalam nasihat-nasihat yang ada dalam Gurindam Dua Belas. Demikian juga ketika mambahas tentang sistem politik dan tata kelola pemerintahan, maka warna Al-Ahkam Al-Sulthaniyyah karya Al-Imam Al-Mawardi begitu kental Pengaruh fikih siyasah dalam pemikirannya ini juga muncul dalam karya-karyanya terutama kitab Tsamarât Al-Mubimmah dan kitab Muqaddimah fi Intizham.

Adapun kondisi sosio kultur dan geopolitik yang melingkupi kehidupan Raja Ali Haji turut membentuk pola pikir dan sangat tercermin dari karya-karya yang dihasilkannya. Tradisi intelektual berupa interaksi yang intensif Raja Ali Haji dengan ulama yang bermastautin di Pulau Penyengat atau dalam berbagai mauhibah beliau seperti ke Makkah, Kairo, Betawi, dan lainnya, serta interaksinya dengan teks-teks klasik dari Al-Ghazâli, Al-Mâwardi, Al-Nawawi, AlAnshâri dan teks-teks lokal melayu karya Al-Sinkili, Al-Fatani, Al-Palimbani dan 
lainnya terlihat menunjukkan pengaruh yang cukup signifikan dalam sepak terjang praktik politik dan pemikiran Raja Ali Haji. ditambah lagi jam terbang Raja Ali Haji sebagai praktisi pemerintahan yang bermu'âyasyah dengan persoalan ketatanegaraan di lingkungan Kerajaan Riau-Lingga memberikan pengaruh langsung dalam pemikirannya, khususnya dalam ranah politik, perundangan, dan ketatanegaraan. $^{82}$

Sinergi yang tampak harmonis antara Raja Ali Haji - dalam posisi sebagai mufti maupun penasehat Raja dan beberapa orang Yang Dipertuan Muda Riau dalam upaya restorasi kebudayaan Melayu Islam dalam kehidupan kenegaraan di lingkungan kerajaan Riau-Lingga ${ }^{83}$ merupakan bukti empirik adanya pengaruh yang signifikan dari tradisi intelektual Raja Ali Haji, lebih spesifik pengaruh fikih siyasah dalam kehidupan Raja Ali Haji.

Setelah mencoba untuk mengkaji dan menganalisa apa yang menjadi buah pikiran Raja Ali Haji khususnya dalam bidang Fiqih Siyasah, maka dapat disimpulkan bahwa pengaruh Hujjatul Islam Al-Imam Al-Ghazali membuat pemikiran politik Raja Ali Haji masuk dalam kategori corak etis yaitu corak yang memberikan penekanan terhadap etika pemegang kekuasaan. Tetapi, pada saat

${ }^{82}$ Achmad Syahid, Pemikiran Politik, h. 134

${ }^{83}$ Sebut saja misalnya pada masa pemerintahan Yang Dipertuan Muda Riau VIII Raja Ali, saat Raja Ali Haji menjadi mufti sekaligus penasehat kerajaan, kaum wanita diperintahkan bertudung, digalakkannya musyawarah terkait dengan segala urusan kerajaan, menyiapkan guruguru untuk mengajar pegawai-pegawai kerajaan, memberikan hukuman kepada pelaku kejahatan seperti berjudi dan menyabung, perompak dan bajak laut, bahkan ada yang dibuang (penjarakan) di Betawi. Lihat: Raja Ahmad dan Raja Ali Haji, Tuhfat Al-Nafis, h. 341-342, juga Barbara Watson Andaya dan Virginia Matheson, Raja Ali Haji: Antara Pemikiran Islam dan Tradisi Melayu, Jurnal Studi-studi Islam Al-Hikmah, No. 14, Vol VI, Tahun 1995, h.123-124 yang sama pemikiran politik Raja Ali Haji juga termasuk dalam kategori corak hukum karena mengemukakan teori-teori yang berfokus pada teori legitimasi penguasa dari sudut pandang hukum Islam sebagaimana teori-teori yang dikemukakan Al-Imam Al-Mawardi dalam Al-Ahkam Al-Sulthaniyyah yang merupakan karya monumental AlMawardi.[]

\section{DAFTAR PUSTAKA}

Abdullah, Muhd. Saghir, Perkembangan Imu Figh dan Tokoh-tokohnya di Asia Tenggara, Solo: CV. Ramadhani, 1985

Filologi Melayu, jilid 4, 1995

Alatas, S. H. Mitos Pribumi Malas, Jakarta, LP3ES, 1988

Alfian, Teuku Haji Ibrahim, Raja Ali Haji Ibn Abmad Sastrawan dan Budayawan Tersohor Dari Riau, Makalah ditulis atas undangan Pemerintah Kota Tanjungpinang dalam rangka pengusulan Raja Ali Haji sebagai Pahlawan Nasional dan terkodifikasi dalam buku Sejarah Perjuangan Raja Ali Haji Sebagai Bapak Bahasa Indonesia

Ali, Fachry, Pasang Surut Peranan Politik. Ulama sebuah kerangka bipotesa struktural, dalam Prisma, No. 4, April 1984

Al-Andalusi, Ibnu `Athiyyah, Al-Muharrar Al-Wajiz fi Tafsiril Kitab Al-Azir, Beirut: Dar al-Kutub al-Ilmiyyah, cet 1,1422

Al-Anshari, Abu Yahya Zakariyya ibn Muhammad, Fath Al-Wabhab bi Syarb Al-Minhaj, ttp: Dar Al-Fikr, 2002

Al-Banna, Hasan, Kumpulan Risalah Dakwah Hasan Al-Banna, Jakarta: Al-I'tishom, 2007

Al-Bukhari, Shahih al-Bukhari, Beirut: Dar Ibn Ktsir al-Yamamah, $1407 \mathrm{H}$

Al Faraby, Abu Nashr, As Siyâsah Al Madaniyah, tahqiq dan syarah 'Ali Bu 
Milham, Beirut: Dar Maktabah Al Hilal, 1994

Al-Farra', Abu Ya'la Muhammad ibn Husain, Al-Abkam Al-Sulthaniyyah, Beirut: Dar Al-Kutub Al-'Ilmiyyah, 2000

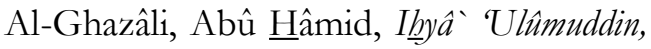
tt: Dâr Asy-Sya’bi, tt Al-Iqtishâd fi Al-I'tiqâdi, Ankara: Nur Matbaasi Universitas Ankara, 1962

Al- Khallaf, Abdul Wahhab, Al-Siyasah wa al-Syariah, Kairo: Daar al-Anshar, 1977

Al-Khin, Mushthafa, Al-Fiqh Al-Manbaji 'Ala Madzhab Al-Imam Al-Syafi'iy, Serbia: al-Fithrah, tt

Al-Mawardi, Ali bin Muhammad bin Habib, Al-Abkam Al-Sulthaniyyah Wa Al-Wilayat Al-Diniyyah, Kuwait: Maktabah Daar Ibnu Qutaibah, 1409

Al-Qusairiy, Abi al-Hasan Muslim alHajjâj, Shabîh Muslim, Beirut, Dar aljiil, tt

Al-Wakil, Muhammad Sayyid, Wajah Dunia Islam Dari Dinasti Bani Umayyah Hingga Imperialisme Modern, Jakarta : Pustaka Al-Kautsar, 1998

Alwasliyah, A Chaider, Pokoknya Kualitatif - Dasar-Dasar Merancang dan Melakukan Penelitian Kualitatif, Jakarta: PT Dunia Pustaka Jaya dengan Pusat Studi Sunda, 2002

Ambary, Hasan Muarif (et. al.), Suplemen Ensiklopedi Islam 2, Jakarta: Ichtiar Baru Van Hoeve, 1966

Andaya, Barbara Watson dan Virginia Matheson, Raja Ali Haji: Antara Pemikiran Islam dan Tradisi Melayu, Jurnal Studi-studi Islam Al-Hikmah, No. 14, Vol VI, Tahun 1995

Ash-Shiddieqy, Hasbi, Imu Kenegaraan Dalam Fikih Islam, Jakarta: PT. Bulan Bintang, 1991

As-Suyuthi, Abdul Rahman Abu Bakr, AlAsybah Wa Al-Nadlair, Beirut: Dar Al-Kutub Al-Ilmiyyah, $1403 \mathrm{H}$
As-Syanqithi, Muhammad Amin, Adbwa ul bayan fi idhoh Al-Qur an bil Qur an, Jeddah: Mathba'ah alMu 'tamar al-Islamy, tt

Asti, Badiatul Muchlisin, "Raja Ali Haji: Menggores Pesan-pesan Dakwah Lewat Bait-bait Gurindam" http://sosok.kompasiana.com/201 2/01/14/raja-ali-haji-menggorespesan-pesan-dakwah-lewat-baitbait-gurindam/, diakses tanggal 15 Juni 2018

Audah, Abdul Qadir, Al-Islam wa Audho'una Al-Siyasiyyah, (Kairo: Dar al-kitab al-'arabi, 1957)

Az-Zuhaili, Wahbah, Al-Fiqh Al-Islamiy Wa Asillatubu, Damaskus: Daar AlFikr, $1405 \mathrm{H}$

Badrun, Ahmad, Gurindam Duabelas: Sebuah Pertemuan Dengan Raja Ali Haji, Makalah ditulis atas undangan Pemerintah Kota Tanjungpinang dalam rangka pengusulan Raja Ali Haji sebagai Pahlawan Nasional dan terkodifikasi dalam buku Sejarah Perjuangan Raja Ali Haji Sebagai Bapak Bahasa Indonesia .

Bruinessen, Martin van, Kitab Kuning, Bandung: Mizan, 1999

Karel A. Steenbrink, Pesantren, Madrasah, dan Sekolah: Pendidikan Islam Dalam Kurun Modern, Jakarta: LP3ES, 1986

Dahlan, Abdul Aziz, et.al, Ensiklopedi Hukum Islam, Jilid 5, Jakarta: Ichtiar Baru van Hoeve, 1996

Djamaluddin, Irwan, Mengisi Roh Ke Dalam Jasad Upaya Memaknai Pesan AyatAyat Gurindam Duabelas Raja Ali Haji Sebagai Ideologi Untuk Menggugat Semangat Zaman, Yogyakarta, Penerbit Navila, 2007

Fathurahman, Oman dan Jajat Burhanudin, Raja Ali haji dan Bahasa Indonesia, Makalah ditulis atas undangan Pemerintah Kota Tanjungpinang dalam rangka pengusulan Raja Ali Haji sebagai Pahlawan Nasional dan terkodifikasi dalam buku Sejarah 
Perjuangan Raja Ali Haji Sebagai Bapak Bahasa Indonesia http:/ / anomalisemesta.blogspot.co $\mathrm{m} / 2007 / 10 /$ tokoh_22.html , diunduh pada tanggal 17 Agustus 2018

Gottschalk, Louis, Mengerti Sejarah, Jakarta: UI Press, 1986

Haji, Raja Ali dan Raja Ahmad, Tuhfat AlNafis, Kuala Lumpur: Penerbit Fajar Bakti, 1982

, Tsamarat Al-Mubimmah Dhiyafah ila al-Umara wa al-Kubara li Abl alMabkamah, cor. or. W. 18

$\longrightarrow$ Kitab Pengetabuan Bahasa, Pekanbaru: Departemen Pendidikan dan Kebudayaan, 1986/1987

Hamidy, UU, makalah Hilang Jasa Kapak Oleh Jasa Ketam: Peranan Raja Ali Haji dalam Perwujudan Bahasa Indonesia

Harahap, Syahrin, Metodologi Studi Tokoh Pemikiran Islam, Jakarta: Prenada Media Grup, 2011

Ikram, Achdiati, Raja Ali Haji, Pablawan Budaya, Makalah ditulis atas undangan Pemerintah Kota Tanjungpinang dalam rangka pengusulan Raja Ali Haji sebagai Pahlawan Nasional dan terkodifikasi dalam buku Sejarah Perjuangan Raja Ali Haji Sebagai Bapak Bahasa Indonesia

Jazuli, A., Fiqh Siyasab: Implementasi Kemaslahatan Umat dalam Ramburambu Syariah, Jakarta: Kencana Prenada Media Group, 2007

Junus, Hasan, Raja Ali Haji Budayawan Di Gerbang Abad XX, Pekanbaru: UNRI Press, 2002

, Sejarah Perjuangan Raja Ali Haji Sebagai Bapak Bahasa Indonesia, Pekanbaru: UNRI Press, 2004

http://kabarnet.wordpress.com/2010/09 /08/karakteristik-kepemimpinanideal-menurut-raja-ali-haji-danrelevansinya-dengan-prinsipprinsip-tata-kelola-pemerintahan-di- indonesia. diunduh pada tanggal 2 September 2018

Kridalaksana, Harimurti, Raja Ali Haji: Pembuka Cakrawala Bahasa Dalam Dunia Melayu, Makalah ditulis atas undangan Pemerintah Kota Tanjungpinang dalam rangka pengusulan Raja Ali Haji sebagai Pahlawan Nasional dan terkodifikasi dalam buku Sejarah Perjuangan Raja Ali Haji Sebagai Bapak Bahasa Indonesia

Kurniawan, Sekilas Tarekat Qadiriyah Naqsyabandiyah, Makalah dipublikasikan pada situs: http://jalanwali.blogspot.com/2011 /10/sekilas-tarekat-qadiriyahwa.html

Luthfi, Muchtar, et. al., Sejarah Riau, Pekanbaru: Biro Bina Sosial, Setwilda Tingkat I Riau. 1998/1999

Mahayana, Maman S., Raja Ali Haji: Bapak Kesusasteraan Melayu, artikel dimuat di http://mahayanamahadewa.com/2010/10/14/rajaali-haji-bapak-kesusastraanmelayu/, diunduh pada tanggal 20 Juli 2012

Mahdini, Tsamarat Al-Mubimmab: Pemikiran Raja Ali Haji Tentang Peradilan, Pekanbaru: Penerbit Yayasan Pusaka Riau, 1999

Meuraxa, Dada, Sejarah Kebudayaan Sumatera, (tt : Firma Hasmar, 1974)

Muthari, Abdul Hadi Wiji, Raja Ali Haji: Ulil Albab Di Persimpangan Zaman, Makalah ditulis atas undangan Pemerintah Kota Tanjungpinang dalam rangka pengusulan Raja Ali Haji sebagai Pahlawan Nasional dan terkodifikasi dalam buku Sejarah Perjuangan Raja Ali Haji Sebagai Bapak Bahasa Indonesia

Osman, Mohd. Taib, Raja Ali Haji: Apakah beliau Seorang Tokob Transisi Atau Pujangga Klasik Yang Akbir Sekali?, (Kuala Lumpur: Dewan Bahasa dan Pustaka Kementrian Pendidikan Malaysia, 1976) 
Pulungan, J. Suyuthi, Fiqh Siyâsah: Ajaran, Sejarah, dan Pemikiran, Jakarta: PT RajaGrafindo Persada, 1994

Putten, Jan van der dan Al-Azhar, Dalam Berkekalan Persababatan Surat-surat Raja Ali Haji kepada von de Wall, Jakarta: Kepustakaan Populer Gramedia, 2007

Rahman, Nurhayati, Raja Ali haji: Penegak Tiang Agung Peradaban di Asia Tenggara, Makalah ditulis atas undangan Pemerintah Kota Tanjungpinang dalam rangka pengusulan Raja Ali Haji sebagai Pahlawan Nasional dan terkodifikasi dalam buku Sejarah Perjuangan Raja Ali Haji Sebagai Bapak Bahasa Indonesia

Reid, Anthony dan David Marr, Dari Raja Ali Haji Hingga Hamka: Indonesia Masa Lalunya, terjemahan. Th. Sumartana, Jakarta: Grafiti Press, 1983

Saleh, Siti Hawa Haji, Cendikia Kesusasteraan Melayu Tradisional, Kuala Lumpur: Dewan Bahasa dan Kementerian Pelajaran Malaysia, 1987

Salim, Rizal, "Raja Ali Haji dan Gurindam 12: Sebuah Karya Maha Agung", http://www.qcritkarpol.com/rajaali-haji-dan-gurindam-12-

sebuahkarya-maha-agung diakses tanggal 30 September 2018

http://www.rajaalihaji.com/id/biography. php diakses pada tanggal 20 Juni 2018

Sham, Abu Hassan, Puisi-puisi Raja Ali Haji, (Kuala Lumpur: Percetakan Dewan Bahasa dan Pustaka Kementerian Pendidikan Malaysia, 1993)

Suryabrata, Sumadi, Metodologi Penelitian, Jakarta: Rajawali Press, 2004

Syahid, Achmad, Pemikiran Politik dan Tendensi Kuasa Raja Ali Haji, Jakarta: Puslitbang Lektur Keagamaan Badan Litbang dan Diklat Departemen Agama RI, 2009
Taimiyah, Taqiyuddin Ahmad ibn Abdissalam ibn, Al-Siyasah AlSyar'iyyah fi Isblabi al-Ra'i walRa'iyyah, Beirut: Dar al-afaq aljadidah, $1403 \mathrm{H}$

van Ronkel, Ph. S. Adat Istiadat Raja-Raja Melayu Leiden; Brill, 1919

174 Perada: Jurnal Studi Islam Kawasan Melayu, Vol. 2, No. 2, Desember 2019 